\title{
Meningen der gik tabt
}

\section{Om begrebsapparater i nyere forskning i det 2 . århundredes liturgi}

\author{
Ph.d.-studerende Robert Bonde Nielsen Hansen
}

\begin{abstract}
Until a couple of decades ago, few scholars of the liturgy of the early church doubted that the Eucharistic and Baptismal rites of the early church could be traced back to the institution of these rites by Jesus Christ, or the Apostles in Jerusalem around the year 30. This view has in later years been challenged, and it is today commonly held that we are unable to reconstruct a primordial rite dating back to Jesus or the Apostles. Supposedly, we are also unable to find common elements in the earliest Christian rites, which appear to be solely regional phenomena. Even though this latter view may to a large extent be true, this article argues that the semantics of minimalism used to describe the liturgy should be supplemented with an acknowledgement of commonly shared themes in the material. Following this line of inquiry, I suggest that whereas one cannot trace the Eucharistic and Baptismal rites of the $2^{\text {nd }}$ century back to Jesus, they nonetheless have a number of elements in common, namely eschatological and sacrificial themes.
\end{abstract}

Key words: Liturgy - Eucharist - Baptism - Eschatology - Sacrifice Semantics $-2^{\text {nd }}$ century.

\section{Indledning}

I ældre liturgiforskning regnede de fleste forskere, som beskæftigede sig med den tidlige kirkes liturgi, med, at beskrivelser af dåben og eukaristien, som stammede fra den tidlige kirke, kunne spores tilbage til Jesu indstiftelse af disse riter, eller i det mindste til apostlenes indstiftelse. ${ }^{1}$ Dette blev f.eks. hævdet af de tyske forskere Ferdinand Pr-

1. Perioden kan ikke afgrænses klart, men det er rimeligt at hævde, at den tager sin begyndelse med opkomsten af den moderne historisk-kritiske forskning og varer ved indtil for ca. 25 siden, selvom også teologer i perioden før den historiske kritik plejede at hævde, at deres liturgiske riter var indstiftet af Herren selv. Se for øvrigt gennemgangen af forskningshistorien angående dette emne i Paul. F. 
obst og Anton Baumstark. ${ }^{2}$ Forskere som f.eks. Hans Lietzmann eller Gregory Dix mente ganske vist ikke, at de kunne identificere en udgave af eukaristien eller dåben, der var officielt vedtaget, men fastholdt dog forestillingen om, at "urformer/urstrukturer" kunne identificeres. ${ }^{3}$ At der var forskel på de forskellige beskrivelser blev ikke nødvendigvis betragtet som en uoverstigelig forhindring. Hvis en rite af en eller anden grund afveg for meget fra det anerkendte mønster, kunne det altid erklæres, at dette specifikke eksempel stammede fra en hæretisk gren af kristendommen, eller at det tilhørte en underkategori indenfor denne rite. Således er det ofte blevet hævdet, at nadverbønner, som ikke indeholdt indstiftelsesordene - som f.eks. Didake 9-10 og Addai og Maris nadverbøn - i virkeligheden var beskrivelser af agapemåltider og ikke af eukaristien. Dette er et emne, som vi vil se nærmere på i det følgende.

Liturgisk forskning indenfor oldkirken blev således ofte reduceret til at finde frem til, hvad der var fælles i de kilder, som man havde adgang til. Hvad der var fælles, måtte således gå tilbage til et tidligere forlæg, og ved på denne måde at skrælle alle forskelle væk kunne man nå frem til liturgien, som Jesus og hans apostle havde indstiftet og fej-

Bradshaw, The Search for the Origins of Christian Worship: Sources and Methods for the Study of Early Liturgy (New York: Oxford University Press 2002), 1-20.

2. Ferdinand Probst, Liturgie der drei ersten christlichen Jahrhunderte (Darmstadt: Wissenschaftliche Buchgesellschaft 1968 [1870]), fremsatte den teori, at beskrivelsen af eukaristien i bog 8 af de Apostolske Konstitutioner var den, apostlene officielt havde vedtaget. Anton Baumstark fulgte delvist Probst i de tidlige dele af sin forskning, jf. Anton Baumstark, Vom geschichtlichen Werden der Liturgie (Freiburg: Herder \& Co. Verlagsbuchhandlung 1923), $7 \mathrm{ff}$.

3. Lietzmanns og Dix' teorier kan betragtes som en slags mellemstadie mellem ældre og nyere forskning. Mens de på den ene side afviste teorien om, at alle liturgiske fænomener i oldkirken kunne spores tilbage til ét oprindeligt forlæg, der stammede fra Jesus eller apostlene, så fastholdt de dog forestillingen om urformer eller strukturer, som kunne identificeres i de foreliggende tekster. Således f.eks. Lietzmanns berømte teori om eukaristiens dobbelte oprindelse. Lietzmann mente, at oldkirkens eukaristibønner kunne spores tilbage til en af to oprindelige former; dels et jødisk, der gik tilbage til urmenigheden i Jerusalem og var en fortsættelse af de måltider, som den historiske Jesus havde holdt med sine disciple, dels et måltid, der var indstiftet af Paulus til minde om Jesu sidste måltid, der var præget af hellenistiske forestillinger. Jf. Hans Lietzmann, Messe und Herrenmahl: Eine Studie zur Geschichte der Liturgie (Bonn: A. Marcus und E. Webers Verlag 1926), 249ff. Selv Gregory Dix, som kritiserede teorien, opgav den ikke, men reformulerede den i sit nu klassiske værk The Shape of the Liturgy (Glasgow: Dacre Press 1947), idet han hævdede, at ikke riternes ordlyd som sådan, men derimod deres struktur eller form kunne spores tilbage til et apostolisk forlæg. Fælles for Lietzmanns og Dix' teorier og ældre forskning er en tro på, at foreliggende riter kan spores tilbage til én eller ganske få "ur"-former, hvis ophav er Jesus eller apostlene. 
ret den. Probst formulerede det som følger: “...dass von den Tagen der Apostel bis zu Ende des vierten Jahrhunderts der Messritus im Wesentlichen derselbe war". Endnu tydeligere blev det, når Probst behandlede Justins Apologi med ordene: "Nachdem der, im Jahre 103 geborene, Justin den am Sonntage gefeierten eucharistischen Gottesdienst beschrieben hat, schliesst er mit den Worten: 'Das ist der Sonntag, an dem er seinen Aposteln und Jüngern erschien und sie das lehrte, was wir euch (den römischen Kaisern) zu Erwägung übergeben haben.' Der Zusammenhang zeigt evident, dass das Uebergebene die Feier der Eucharistie betrifft, über welche Jesus die Apostel nach der Auferstehung belehrte."4

Siden er der sket et forskningsmæssigt paradigmeskift. Den tidlige kirkes dåbs og nadverriter kan hverken spores tilbage til en enkelt fælles kilde eller til blot to eller tre forskellige kilder, som det f.eks. blev hævdet i sin tid af Probst. Tværtimod har moderne forskning overbevisende påpeget, at diversiteten i disse riter er lige så stor som diversiteten i urkristendommen selv, der i vid udstrækning afspejler den omgivende religiøse, sociologiske og kulturelle kontekst. I stedet må de forskellige riter og liturgier, der er beskrevet i tidlige kristne tekster, ses som i bedste fald regionalt forekommende fænomener. Blandt de mest kendte eksponenter for dette synspunkt er Paul F. Bradshaw ${ }^{5}$ og Andrew McGowan. ${ }^{6}$

I det følgende ønsker jeg at pege på en række problemstillinger i forbindelse med dette paradigmeskift og i forlængelse heraf at komme med de første spæde forslag til en løsning på dem. Der skal argumenteres for, at der rent faktisk fandtes forestillinger, som var fælles for eukaristi- og dåbsriter og refleksioner over dem. Disse bandt dem ikke sammen til et forenet fælles system - sådan som man i visse tilfælde ville kunne beskrive moderne konfessioner - men i det mindste til et hele, som kan beskrives ved brug af begreberne "eskatologi" og “offerterminologi” i det 2. årh.

4. Ferdinand Probst Liturgie des vierten Jahrhunderts und deren Reform (Münster: Aschendorffschen Buchhandlung 1893), 5 og 12.

5. Bradshaw er overordentligt produktiv, men her skal blot nævnes Bradshaw (2002), x: “...what we do know about patterns of worship in that primitive period points towards considerable variety....we need to specify where the practice in question is encountered (Syria, Egypt, North Africa, Rome, or some other region) and when", eller Paul F. Bradshaw, Daily Prayer in the Early Church, A Study of the Origin and Early Development of the Divine Office (London: Alcuin Club/SPCK 1981), 150.

6. Jf. Andrew McGowan, Ascetic Eucharists, Food and Drink in Early Christian Ritual Meals (Oxford: Clarendon Press 1999), 27: "An acceptance of diversity, and hence a certain retreat from claims to unitary or even dichotomous eucharistic origins, is a necessary step before further progress can be made." 


\section{Terminologien i nyere liturgisk forskning}

Af nogle forskere hæudes det, at det eneste der forenede den tidlige kirkes eukaristi- og dåbsriter var, at der var tale om henholdsvist et religiøst måltid og en optagelsesrite, der involverede vand (eller evt. kun olie). ${ }^{7}$ Der var ikke noget fælles teologisk indhold. Meningen med eukaristi og dåb var ustabil og vekslende fra tekst til tekst og fra sted til sted. En række eksempler skal i det følgende anføres.

Variationer i dåbsriter kan fremdrages ved bl.a. at se på forskellen mellem f.eks. Didake 7 og Thomasakterne. ${ }^{8}$ I forbindelse med disse to tekster kan man også kort nævne Rom 6. ${ }^{9}$ Didake 7 foreskriver en

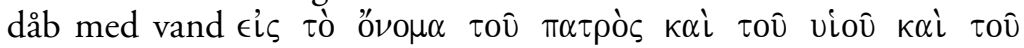

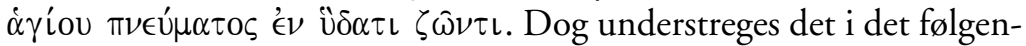
de, at hvis man ikke har adgang til levende (rindende) vand, kan andet vand til nød bruges. Før dåben skal såvel den, der døber, som den, der skal døbes, faste.

Overfor denne enkle beskrivelse af dåben er der de mange beskrivelser af dåben i Thomasakterne, som ikke engang er ensartede inden

7. Således f.eks. Bryan D. Spinks, Early and Medieval Rituals and Theologies of Baptism: From the New Testament to the Council of Trent. Liturgy, Worship and Society (Aldershot: Ashgate 2006) 12ff. og 35: "The early evidence allows us only to document what happened in certain places at certain times, and it is not sufficient to build some universal picture", eller endnu tydeligere Paul Bradshaw, Early Christian Worship - A basic introduction to ideas and practice (Collegeville, MI: The Liturgical Press 1996), 2: "As a result, what we find in the New Testament is not one standard theology of baptism or a systematized explanation of what it means to become a Christian, but a variety of ways of speaking about that experience, quite different images being employed by different writers in their attempts to communicate it to others". Jf. også Holger Hammerich, Taufe und Askese - Der Taufaufschub in vorkonstantinischer Zeit (Hamburg 1994, ikke publiceret doktorafhandling), 84 .

8. Thomasakterne er formentlig fra begyndelsen af 3. årh. (220-230), men er her inddraget som en del af tekster fra 2. årh. Dette har flere årsager. Dateringen af Thomasakterne er meget omstridt, og skønt teksten som sådan ikke kan spores tilbage til 2. årh., så synes væsentlige dele af teksten at kunne. Det er endvidere tvivlsomt, om man kan operere med en afgrænsning, af 2. årh., der udelukker alt materiale, som falder udenfor perioden. I det mindste inden for angelsaksisk forskning er der tradition for at tale om "the long 18th century" og lade det strække sig fra 1688-1815 eller senere, jeg er Paul Bradshaw tak skyldig for denne iagttagelse. Med denne præcedens in mente og i lyset af, at i det mindste dele af materialet er tidligere samt eksemplets klarhed, tillader jeg mig at henregne Thomasakterne til 2. årh. Der hersker ikke fuldstændig enighed angående inddelingen af Thomasakterne, men jeg følger her den, der er lagt til grund hos Jørgen Ledet Christiansen og Helge Kjær Nielsens Nytestamentlige Apokryfer. Oversattelse, indledning og noter (København: Det Danske Bibelselskab, 2002).

9. Forskellen mellem dåben i Didake 7 på den ene side og Thomasakterne på den anden side er i øvrigt også omtalt hos Paul Bradshaw (2002), 150-154. 
for skriftet selv. Der tales flere steder om seglet, der rimeligvis markerer optagelsen i det kristne fællesskab. Dette er dog ikke nødvendigvis identisk med vanddåben, men derimod en "dåb i olie". Som eksempel på dette kan man betragte beretningen om kong Gundafor og hans broder Gads dåb i kap. 26-27. Vand indgår ikke som en del af ritualet. I stedet salves Gundafor og Gad med olie samtidig med, at Thomas fremsiger en bøn, der ganske vist slutter af med en påkaldelse af treenigheden ligesom Didake 7, men ellers ikke har meget til fælles med den. ${ }^{10}$ Faste omtales ikke som en del af ritualet.

Sidenhen i Thomasakterne i kap. 131-133 beskrives hærføreren Sifors dåb, der både beskrives som dåben og seglet. Salvning med olie omtales også her, men i forlængelse af dette lader apostlen Thomas et kar (med vand?) bringe, hvorefter han døber Sifor og dennes familie. Dåben beskrives her som tilgivelse af synd og det, der føder et nyt menneske. Heller ikke her er faste nævnt. Der er flere beskrivelser af dåben i Thomasakterne, men de synes heller ikke at passe ind i noget klart mønster. I forlængelse af disse eksempler vil jeg blot ganske kort pege på, at Paulus' forestillinger i Rom 6 om dåben som død og opstandelse med Kristus, ikke synes at spille nogen rolle i nogen af dem.

Beskrivelser af eukaristien synes også at være præget af en høj grad af diversitet. En række eksempler kan gives, således Didake 9-10 og Tertullians Apologeticum 39. Didake gengiver eukaristibønner, mens Tertullian beskriver et kristent måltid for ikke-kristne læsere. Det er vanskeligt at sammenligne de to tekster uden videre, men det kan i det mindste slås fast, at de ikke benytter et fælles begreb, idet

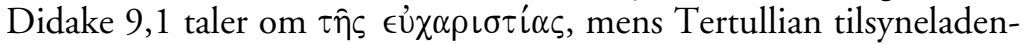
de taler om agapemåltider. ${ }^{11}$ Hertil kommer, at mens Didake 9-10 synes at lægge vægt på den åndelige føde og drik, som indtages i eukaristi måltidet $(10,3)$ og måltidet som opfyldelse af gammeltestamentlige profetier $(9,2.4)$ samt doksologisk materiale $(10,3.5)$, så synes Tertullian at lægge vægt på de kristnes anstændighed i forbin-

10. Denne lyder i Jørgen Ledet Christiansen og Helge Kjær Nielsens oversættelse bl.a.: “...Kom, højeste gave./ Kom, barmhjertige moder./ Kom, delagtighed i det mandlige./ Kom, du der åbenbarer de skjulte hemmeligheder...”, Jørgen Ledet Christiansen og Helge Kjær Nielsen (2002), 373. Forskellene i forhold til Didake er til at få øje på. Hvad angår det teologiske indhold i denne tekst, så har i det mindste Gabriele Winkler argumenteret for, at salvning i tidlig syrisk praksis havde til formål at give den, der skulle døbes, Ånden, så vedkommende kunne tage del i Kristi messiansk-eskatologiske kongedømme. Det synes klart, at dåbens forbillede i denne optik er Jesu dåb i Jordan modsat Paulus' forestilling om dåben som en død og opstandelse med Kristus. Jf. "The Original Meaning of the Prebaptismal Anointing and its Implications”, Worship 52 (1978), 24-45 (36).

11. Jf. Tertullian, Apologeticum, Carl Becker, red., (München: Kösel Verlag 1952) 39,16: "id vocatur quod dilectio penes Graecos." 
delse med måltidet samt det, at de fattige mættes i forbindelse med det. ${ }^{12}$ Også i forbindelse med eukaristien synes der altså, at herske en sådan grad af diversitet i det 2 . årh., at kun en minimal definition af nadveren er mulig i 2 . årh.

Både for dåbens og nadverens vedkommende må der så opereres med minimaldefinitioner, nemlig at der henholdsvis er tale om et optagelsesritual og et religiøst fællesmåltid. Hvorvidt de ritualer, som jeg har nævnt i de anførte eksempler, rent faktisk har været i brug i oldkirken eller ej, kan naturligvis ikke afgøres uden videre. Det er i denne sammenhæng mindre vigtigt. Det afgørende er, at dele af den moderne liturgiforskning har peget på, at de ikke opviser nogen fælles form eller teologi.

Et større arbejde med kristne tekster fra det 2. årh., der berører dåben og nadveren, har imidlertid fået mig til at tvivle på, at det er nødvendigt at nøjes med de minimaldefinitioner, som nyere forskningspositioner opererer med. Dette hænger bl.a. sammen med, at de arbejder med et uklart begreb om "agapemåltider", der ikke er præget af den diversitet, der ellers hævdes.

Fælles kristne måltider nævnes i mange tidlige kilder, f.eks. 1 Kor 10,14ff. I nogle tekster kaldes de kærlighedsmåltider (agape/agapemåltider), f.eks. Jud. 12. Spørgsmålet om forholdet mellem disse måltider og eukaristien er imidlertid omdiskuteret, og nogle af diskussionerne belyser i særlig grad det foreliggende emne. Selv i nyere forskningsmæssige publikationer, der omhandler eukaristien, ${ }^{13}$ kan man se, at agapemåltidet bliver betragtet som et rituelt måltid, der er klart adskilt fra eukaristien.

Agapemåltidet skulle således være et måltid, der blomstrede og fandtes i hele kirken - $\mathrm{i}$ denne forbindelse er diversiteten forsvundet - fra senest midten af det 2. årh., og som tilsyneladende forsvandt omtrent samtidig med, at det vestromerske rige faldt fra hinanden, hvorefter det ikke efterlod nogen spor af dets videre eksistens. Set fra dette perspektiv er det svært ikke at forstå en stor del af den nyere forskning på den måde, at mens den tidlige kirke ikke havde noget, der kunne udgøre en rød tråd i dens eukaristifejring, så havde den til gengæld et rituelt "mod-måltid". Dette skulle være karakteriseret ved en så høj grad af konformitet, at det uden væsentlige problemer kan

12. Ganske vist omtaler Tertullian bønner i forbindelse med måltidet - som han for øvrigt ikke gengiver - men hvilken lighed de faktiske bønner i givet fald har haft med bønnerne i Didake 9-10 må forblive ren spekulation.

13. Jf. f.eks. Kurt Niederwimmer, Die Didache. Kommentar zu den Apostolischen Vätern (Göttingen: Vandenhoeck \& Ruprecht 1993), 178ff. eller Johannes Betz, "The Eucharist in the Didache", The Didache in Modern Research, red. Johnatan A. Draper (Leiden: E.J. Brill 1996), $250 \mathrm{ff.}$ 
identificeres i store dele af det foreliggende materiale. Imidlertid hævdes det samtidig, at der på dette tidspunkt ikke eksisterede en sådan konformitet i kirken. Hvad mere er: Når man ser nærmere på beviserne for eksistensen af et agapemåltid, der eksisterede separat fra eukaristimåltidet i 2 . årh., bliver det i stigende grad klart, at beviserne er meget tvivlsomme. Det er yderligere problematisk, at næsten ingen af de forskere, der taler om forekomster af agapemåltider i det materiale, de arbejder med, giver nogen forklaring på, hvad de mener, når de taler om agapemåltider; i stedet anføres ofte nogle meget vage forklaringer, som ikke bliver underbygget med henvisninger til kilder. ${ }^{14}$

Som eksempel på dette kan Johannes Betz anføres. Han skriver i sin behandling af Didake 9-10 bl.a., at agapemåltidet er "a simple, even though sacral meal (agape)" (Betz, 1996, 247). Videre skriver Betz, at der i Didake 9,2-5 og 10,2-5 er indeholdt "theological peculiarities of the agape material" $(1996,249)$ uden dog at nævne, hvori disse består. Et yderligere eksempel kunne være Kurt Niederwimmer, der om liturgiens forløb i Didake skriver: "Gemeinschaftsmahl (“Agape”?), als Sättigungsmahl” (Niederwimmer 1993, 179). Andre eksempler kunne anføres. De samler sig dog oftest om en række i øvrigt uunderbyggede forestillinger om et måltid, der er symbolsk, og samtidig savner indstiftelsesberetningen.

Det er ganske vist korrekt, at ordet "agape" ofte optræder i den relevante litteratur fra 2. årh. Det er derimod ikke på nogen måde klart, at glosen i sig har indeholdt betydningen af et rituelt måltid, der var klart adskilt fra eukaristien og karakteriseret af en høj grad af ensartethed. Det er i det mindste plausibelt at hævde, at når glosen "agape" optræder i tidlige kristne skrifter, er den snarere et synonym for eukaristien. Jeg vil hævde, at når man kigger nærmere på forskningshistorien i forbindelse med eukaristi og agape, synes det at blive mere og mere klart, at "agape" bliver brugt som en slags depot, hvor man anbringer de beskrivelser af eukaristien, som ikke harmonerer med forskernes forudfattede idéer om, hvordan den blev fejret af de tidlige kristne. ${ }^{15}$ Dette har således ofte været tilfældet med ritualerne,

14. Det er interessant, at der kun er én forsker, der har forsøgt at beskrive agapemåltidet sammenhængende i stedet for blot at henvise til det, nemlig Karl Völker, Mysterium und Agape, Die gemeinsamen Mahlzeiten in der alten Kirche (Gotha: Leopold Klotz Verlag 1927).

15. Teorier om agapemåltidet kan - vel delvis pga. teoriens vage udformning - variere mere end fremstillingen ovenfor lader ane. Dette kan man overbevise sig om ved at konsultere bl.a. Lietzmann (1926), Betz (1996), 247, eller Clayton N. Jefford (red.), The Didache in Context - Essays on Its Text, History, and Transmission (Leiden: E.J. Brill 1995). Således vælger Lietzmann, som allerede nævnt, at tale om et dobbelt ophav til eukaristien. Dette ændrer dog ikke synderligt ved, at 
der er beskrevet i Didake 9-10 og Addai og Maris nadverbøn. Det er bl.a. Betz (Betz 1996, 248f.), der hævder, at den manglende indstiftelsesberetning skulle være et kriterium for identifikationen af et agape måltid.

Det er således et interessant faktum, at mens den moderne liturgiforskning i praksis har opgivet forsøget på at spore den tidlige kirkes liturgi tilbage til en idealiseret original, så gør den i vid udstrækning stadig brug af et koncept, som blev skabt - om end næsten sikkert på et ubevidst plan - til at udgøre et teoretisk fundament for netop denne teori. Dette synes i sig selv at pege på dybereliggende problemer i den moderne forståelse af oldkirkens liturgi.

Men for at vende tilbage til, hvad der blev antydet tidligere. Den moderne liturgiforskning vil hævde en vidtgående diversitet både $\mathrm{i}$ den liturgiske praksis og i den dermed forbundne teologi, og den vil forklare denne diversitet med en henvisning til de mangfoldige rituelle udtryk i samtidige jødiske og hedenske tekster. Hvis diversiteten var så omfattende, ${ }^{16}$ måtte det anerkendes, at liturgi-forskningen må lade sig nøje med en række minimaldefinitioner i forhold til denne periode. ${ }^{17}$ Det er imidlertid ikke indlysende, at de os tilgængelige kilder skal fortolkes på ovennævnte måde. I stedet vil alternativer i det følgende forsøges etableret på baggrund af de forhåndenværende kilder.

\section{Alternativer}

Det må fra begyndelsen slås fast, at vi ikke umiddelbart kan tale om de kristnes "dåb" eller "nadver" i 2. årh., dertil varierer de forskellige beskrivelser, der er bevaret i kilderne, for meget. ${ }^{18}$ Yderligere savner

man overordnet må fastholde rigtigheden af ovenstående teori om agapemåltidet som en måde, hvorpå forskere har haft mulighed for at se bort fra uønsket materiale på.

16. Jf. f.eks. John W. Riggs, “The Sacred Food of Didache 9-10”, red. Clayton N. Jefford (1995), 256ff.

17. Således er der i de senere år kommet flere artikler og monografier, der hævder at handle om dåben og nadveren i oldkirken, men som ender med at slå fast, at disse begreber ikke dækkede over noget fast indhold i oldkirken, men kun over regionale forekomster, som alene havde et aspekt af optagelsesrite henholdsvis måltid tilfælles, og således ikke havde nogen fast "begrebsmæssig" kerne. Jf. f.eks. Bryan D. Spinks (2006), 157f. eller Paul Bradshaw (2002), 231. På den ene side kan sådanne "minimaldefinitioner" for så vidt godt fungere, men tømt for snart sagt alt indhold er det vanskeligt at se, hvordan noget relevant kan siges om disse kategorier.

18. Et enkelt banalt om end tydeligt eksempel er, at mens Didakes eukaristibøn (Didake 9,1-5) indleder med bægeret, så indleder Justin i sin ikke helt enkle beskri- 
vi brugbare kriterier til at afgøre, hvad der kan beskrives som kristne kilder/grupper i modsætning til hæretiske og/eller udbryder grupper; videre hvornår er der tale om hæretiske kristne, og hvornår er der tale om ikke-kristne gnostiske grupper, der blot havde optaget et minimalt kvantum af kristeligt tankegods. Dette afhænger igen af, hvorvidt en sådan skelnen overhovedet er formålstjenlig endsige mulig. Det synes at være en mere konstruktiv tilgang at bløde op i de meget skarpe beskrivelser af de tidlige kristne og i stedet anerkende, at en bred vifte af grupper i det 2. årh. kan beskrives som kristne uden nødvendigvis at beslutte, at den ene eller den anden ende af spektret bør beskrives som hæretisk eller ortodoks. Dette gælder ikke mindst, fordi det bør anerkendes, at en lang række grupper, som på et eller andet tidspunkt er blevet beskrevet som hæretiske, betragtede sig selv som rettroende kristne. ${ }^{19}$

Som et lille indskud kan det nævnes, at dette sidste punkt kaster lys over, hvorfor det ofte har været et stridspunkt, hvilke beskrivelser af/ refleksioner over liturgien, der skal betragtes som kristne, sådan som den refererede diskussion om berettigelsen af at tale om et agapemåltid i oldkirken også afslører (McGowan 1999, 12-18).

Det synes altså at være klart, at det 2. årh.s kristendom var af en sådan diversitet og kompleksitet, at det kan være fristende at betragte de forskellige menigheder som forskellige religioner i stedet for udtryk for det samme fænomen. ${ }^{20}$ Men dette er ikke hele billedet. Når man ser på kilderne fra 2. årh., bliver det hurtigt klart, at de tidlige kristne forfattere ikke selv mente, at de tilhørte en række isolerede sekter. Tværtimod var de sig bevidste om, at de - for at bruge en moderne anakronisme - tilhørte et globalt fællesskab. ${ }^{21}$

18. velse af eukaristien (Justin 1. Apologia kap 66) med brødet. Et andet eksempel på denne diversitet er den meget voldsomme forskel i detalje rigdommen mellem f.eks. på den ende side Justins og Didakes forholdsvis enkle eukaristi-bønner og på den anden side den meget detaljerede og udpenslede eukaristibøn i Addai og Maris nadverbøn.

19. Markion og hans tilhængere er et godt eksempel på dette.

20. Man behøver blot at reflektere over diversiteten indenfor dåbsritualer på dette tidspunkt. Mens nogle kristne skrifter fra det 2. årh. insisterer på en salvelse i forbindelse med dåben som værende fuldstændigt uundværlig, er der andre som ikke engang nævner det, jf. i denne forbindelse Bryan D. Spinks (2006), 14ff. Man kunne også pege på den stadigt pågående diskussion om, hvorvidt nogle eller alle gnostiske grupperinger var en del af den tidlige kristendom, jf. f.eks. Karen L. King, What is Gnosticism (Cambridge, Mass.: Belknap Press of Harvard University Press 2003), 5-19 og 239-247.

21. Jf. f.eks. Klemens af Alexandria Stromata bog I, XIX, hvor Klemens gør det helt klart, at kirken er en størrelse, der er tydeligt adskilt fra hæretiske sekter. Det bør dog erindres, at selv om der tydeligvis er tale om parallelle problemstillinger, så kan man ikke uden videre konkludere, at spørgsmålet kristen vs. hæretisk er det 
Det er naturligvis heller ikke muligt ganske enkelt at acceptere fædrenes udsagn. Således kan deres verdenssyn ikke uden videre betragtes som værende objektivt; dette turde være klart for enhver, som har nogen form for kendskab til deres skrifter. Det bør også tages med i betragtning, at deres måde at forstå verden og deres egen tid på er forskellig fra vores. Hvis vi f.eks. kaster blikket på Tertullian, kan vi konstatere, at alle, som ikke var fuldstændigt enige med ham, blev kategoriseret som hæretikere eller skismatikere. ${ }^{22}$ Selvom det ikke er muligt at betragte selvforståelsen i det 2. århundredes kristne skrifter som historisk dækkende, er det forsvarligt at regne med, at de semantiske konstruktioner, som disse udsagn repræsenterer, blev betragtet som værende sande af dem, som formulerede dem. Mens det således næppe er fuldstændigt korrekt, at en kristen fra det 2. årh., der rejste i middelhavsområdet, mødte brødre overalt, hvor han kom frem, ${ }^{23}$ hvis der med udtrykket brødre refereres til personer, som eksakt reproducerede hans egen menigheds riter og ritualer, kan det accepteres som plausibelt, at han rent faktisk mødte folk, som han betragtede som kristne brødre, og med hvem han mente at have noget tilfælles.

Skønt det således ikke kan hævdes, at den kristne kirkes liturgi i 2. årh. udgjorde et fælles hele, og skønt kildernes egne udsagn ikke kan betragtes som kendsgerninger (især eftersom vi ikke befinder os i en situation, hvor det er vores opgave at reproducere eller forsvare deres selvopfattelse), må det på den anden side heller ikke ignoreres, at kilderne enstemmigt hævder, at den kristne "kirke" udgjorde et netværk spredt ud over verden, som i sidste ende rakte tilbage til Jesus og apostlene. Det kan således ikke a priori hævdes, at de tidlige kristne bestod af en række menigheder, der var uafhængige af hinanden, og hvis riter derfor også var fuldstændigt uforbundne. I det følgende vil der derfor blive peget på en række karakteristika ved dåb og eukaristi i 2. årh., som var universelle eller i det mindste næsten universelle. Dette kan betragtes som et foreløbigt forsøg på at påpege, hvori den røde tråd i de tidlige kristnes liturgi bestod.

samme som spørgsmålet om, hvorvidt eukaristi og dåb er forbundet af nogle fælles karakteristika på det pågældende tidspunkt. Det bør dog bestandigt holdes for øje, at i en verden, som i overvejende grad var analfabetisk, og hvor ortodoksi ofte måtte udtrykkes gennem ritualer og/eller formelagtige udtryk, ligger ortodoksi og ortopraksis tættere på hinanden, end man i første omgang kunne være tilbøjelig til at mene. Hvis man i en sådan kontekst ønskede at være ortodoks kristen, var det således ikke alene vigtigt at have de rette meninger, men også de rigtige ritualer og at reflektere over dem på en passende måde.

22. Jf. f.eks. Tertullian, De Praescriptione Hæreticorum, kap XIII-XVII, eller De Baptismo, kap. XV og XVIII.

23. Således som vi læser det i Aberkios indskriften fra Lilleasien. 


\section{Den røde tråd}

Hvis man ser på de - det må indrømmes - relativt sparsomme beskrivelser af og refleksioner over eukaristi og dåb i kirken i det 2. årh., bliver en række karakteristika, som er fælles for langt hovedparten af dem, tydelige. Disse karakteristika synes for en meget stor del at være koncentreret om begreber, som hører hjemme i eskatologien og offerterminologien. I det følgende vil vægten af pladshensyn være lagt på eukaristien og eskatologiens rolle i denne sammenhæng.

Som Wainwright påpegede for næsten fyrre år siden, ${ }^{24}$ så eksisterer der som del af den kristne kirkes eukaristifejring en ofte overset tradition, der forbinder eukaristien med Kristi parousi og herlighedsmåltidet, som de troende er bestemt til at fejre med deres opstandne Herre i Guds Rige. Intetsteds er denne tradition mere fremherskende end i det 2. årh.; hvad mere er, så er eskatologiske træk også en del af dåben på denne tid, som der vil bliver argumenteret for nedenfor.

Til at illustrere de ret omfattende fællestræk i eukaristien i 2. årh. vil udvalgte elementer i Didake 9,1-10,5 blive sammenlignet med dele af Tertullians Apologeticum 39.

Didakes eukaristibønner er overordentligt rige på eskatologiske elementer. Kun enkelte elementer vil blive belyst i det følgende. I Di-

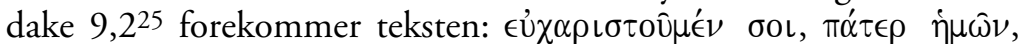

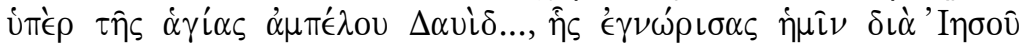

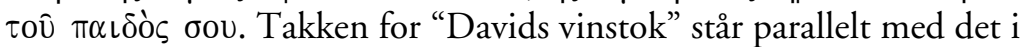

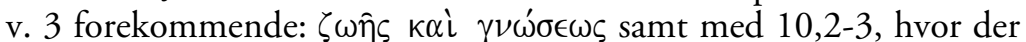

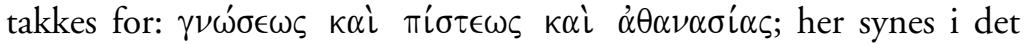
mindste "udødelighed" ret oplagt at være et eskatologisk element. I Ez 19,10-14 bruges vinstokken som billede på det davidiske kongehus. Det er muligt i lyset af v. 3, NTs omtale af Jesus som $\dot{\rho} \iota \alpha$

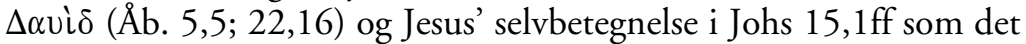
sande vintræ at forstå udtrykket som dækkende over den davidiske Messias (Betz 1996, 266). Flere forskere har desuden peget på, at ver-

24. Jf. Geoffrey Wainwright, Eucharist and Eschatology (Akron, Ohio: OSL Publications, 2. udgave 2002) 2-3: "it may seem that eucharistic theology has throughout the whole history of the church been concerned exclusively with the questions of the presence and the elements, the eucharistic sacrifice...My aim in the present study is not only to do more justice to the importance of the neglected biblical texts for a doctrine of the eucharist, but also to develop in a systematic way the more or less isolated insights into the eschatological character of the eucharist displayed by the liturgies and the earlier theologians". (1. udgaven kom tilbage i 1971).

25. Her og i det følgende er brugt den græske tekst hos Bart D. Ehrman, The Apostolic Fathers I, LCL 24 (Cambridge, Mass.: Harvard University Press 2003). 
sets baggrund skal findes i Sl 80,26 der i tiden omkring kristendommens opståen i lyset af v. 16 og 18 blev tolket som en messiansk salme (Eisler 1926, 9). I 1. årh. findes der desuden i jødedommen en tro på, at den vin, som skal bruges ved det eskatologiske herlighedsmåltid, siden skabelsen har været opbevaret i en "mirakelvinstok", der indeholder uanede mængder af vin, til det gigantiske bæger som kong David selv skal fremsige velsignelsen over; denne vinstok blev undertiden tolket som et billede på Messias (Eisler 1926, 10f). Ud-

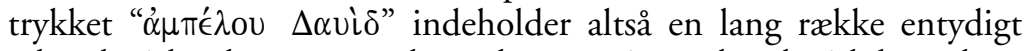
eskatologiske elementer og hører hjemme i en eskatologisk kontekst.

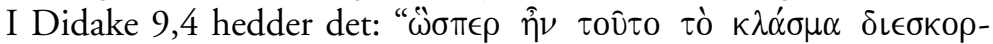

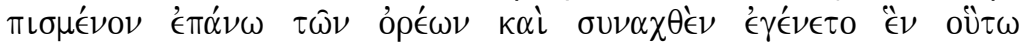

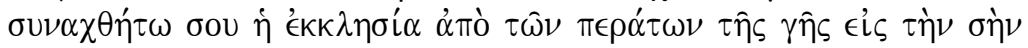

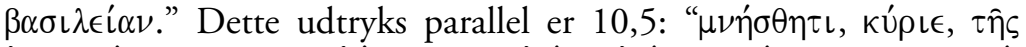

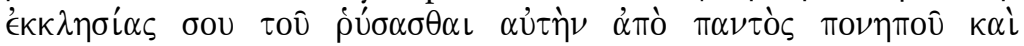

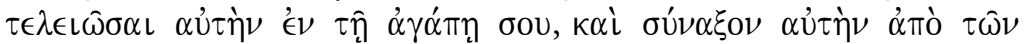

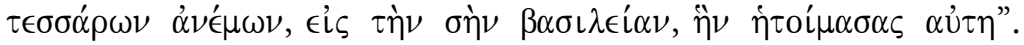
Det er tydeligt, at disse to formuleringer i forbindelse med nadveren er endnu mere eskatologisk prægede end den ovenfor citerede passage fra 9,2. Menigheden, der i 9,2 takkede for den del af de eskatologiske gaver, som de allerede havde del i, beder her om, at de eskatologiske løfter, der endnu ligger ude i fremtiden, må blive til virkelighed. Samlingsmotivet er et velkendt eskatologisk motiv fra GT, hvor det en række steder understreges, at Israel ved tidernes ende skal samles på Zion (Es 11,12; 27,13; Jer 3,17). Forskellen er for så vidt kun, at mens det hos profeterne er Israels samling på Zion, der er i fokus, så er det her kirkens samling i Gudsriget. Endelig kan det anføres, at udtrykket $\mu \nu \eta ́ \sigma \theta \eta \tau \iota$, кúpıє af flere forskere blevet tolket som klart eskatologisk. Argumentet lyder som følger: GT og jødiske kilder udsiger ret entydigt, at når Gud husker, handler han. Bønnen om, at Gud ihukommer sin kirke og frelser den, er en opfordring til handling. Dette har bl.a. Luigi Clerici illustreret med følgende formulering "Wenn Lk. 1,72 sagt, daß Gott seines Bundes "gedenkt" ( $\mu \nu \eta-$ $\sigma \theta \eta \nu \alpha \iota \delta\llcorner\alpha \theta \eta \kappa \eta \varsigma)$, so heißt das, daß Er jetzt die eschatologische Bundesverheißung erfüllt." 27 Selvom henvisningen ikke er til GT, så er den brugbar, al den stund den viser, at traditionen stadig var levende

26. Robert Eisler “Das letzte Abendmahl”, $Z N W 25$, (1926), 5-37 (7). Arthur Vööbus, Liturgical Traditions in the Didache, Papers of the Estonian Theological Society in Exile, Scholarly series 16 (Stockholm: Etse 1968), 124.

27. Luigi Clerici, Einsammlung der Zerstreuten. Liturgiegeschichtliche Untersuchungen zur Vor- und Nachgeschichte der Fürbitte für die Kirche in Didache 9, 4 und 10,5, Liturgiewissenschaftliche Quellen und Forschungen Heft 44 (Münster: Aschendorffsche Verlagsbuchhandlung 1966), 49. 
på nytestamentlig tid. Ud over disse eksempler kan man også pege på bl.a. det eskatologiske Maranatha-råb i 10,6.

I Apologeticum 3928, hvor Tertullian taler om kristnes fællesmåltid, er de eskatologiske elementer skønt mindre udtalte også tilstede. Det er således bemærkelsesværdigt, at Tertullian allerede i de to første vers af kapitlet både bruger formuleringen "et spei foedere" $(39,1)$ og "pro mora finis" (39,2), i begge tilfælde synes der at være tale om klart eskatologiske udtryk. Så i 39,4 følger den meget interessante formulering: summumque futuri iudicii praeiudicium est, si quis ita deliquerit ut a communicatione orationis et conventus et omnis sancti commercii relegetur. ${ }^{29}$ Selvom Tertullian her taler om kristen gudstjeneste $\mathrm{i}$ almindelighed og ikke om eukaristi specifikt, så synes denne at være en del af det, som den syndige kristne udelukkes fra. Det for os interessante i denne sammenhæng er imidlertid, at forestillingen om at være med/være udelukket knyttes sammen med en forestilling om foregribelse af dommen. Den kristne menighed afspejler her i sin skelnen mellem dem, der er inde i henholdsvis uden for menigheden, mikrokosmisk, hvad der skal ske makrokosmisk på dommens dag. Hvorvidt denne foregribelse blev betragtet som mere end symbolsk af Tertullian, er et åbent spørgsmål. Denne forestilling er måske uddybet specifikt i forhold til nadveren i 39,16, hvor det i forbindelse med eukaristien siges, at det ikke forholder sig som hos hedningene - der kun tænker på at mæske sig - men som hos Gud. Citatet lyder: non qua penes vos parasiti adfecant ad gloriam famulandae libertatis sub auctoramento ventris inter contumelias saginandi, sed qua penes deum maior est comtemplatio mediocrium.

Hvis vi kort vender blikket mod eskatologien i andre "eukaristitekster” fra det 2. årh., kan tematikken bl.a. genfindes i passager i Ignatius' breve (f.eks. IgnSmyr. 3,1-3): Ignatius svælger f.eks. i sit brev til romerne $\mathrm{i}$ tanken om sit eget forestående martyrium, hvor han med et billedsprog, der tydeligvis er hentet fra eukaristien, malende udpensler, hvorledes han skal males til et sandt Kristi brød mellem løvernes tænder (IgnRom. 4,1-3). Dette vil ikke kun føre til, at han vil blive et $\theta u \sigma i \alpha$ (offer), men vil også føre til hans fremtidige opstandelse (IgnRom. 4,1-3). Ligeledes refererer Ignatius i brevet til epheserne

28. Netop denne tekst er udvalgt, da de eskatologiske elementer her er langt mindre tydelige end i mange andre tekster (f.eks. Ignatius). At de trods alt alligevel er tilstede, udgør derfor et vigtigst argument.

29. Stykket kan oversættes omtrent: "og størst varsel om den kommende dom er det, hvis én har fejlet, så at han fjernes/udstødes fra fællesbønnen og forsamlingerne og alle hellige handlinger" (min oversættelse). 


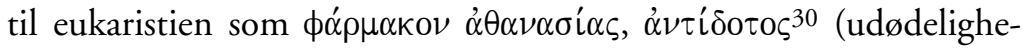
dens medicin, en modgift). Man kunne også pege på Andreasakterne 10-12 eller Addais og Maris nadverbøn, ${ }^{31}$ og andre eksempler kunne også nævnes. ${ }^{32}$ Det kan altså foreløbigt konkluderes, at eskatologiske elementer er tilstede i en række eukaristitekster fra 2. årh.

Yderligere vil jeg tilføje, at selv om det ikke skal hævdes, at disse traditioner alle kan spores tilbage til $\mathrm{Ny}$ Testamente, så er det ikke desto mindre klart, at de også findes dér, som det kan ses fra f.eks. Luk 24,13-35, hvor den opstandne Kristus fejrer et måltid med sine disciple, der oplagt kan fortolkes som en foregribelse af det eskatologiske herlighedsmåltid. Her skal man huske på, at Jesus kun få kapitler tidligere tilsyneladende havde erklæret, at han ville faste indtil det eskatologiske herlighedsmåltid i Gudsrige. ${ }^{33}$ Yderligere eksempler på denne forestilling kan findes i f.eks. 1. Kor, hvor Paulus hævder, at eukaristien prefigurerer mikrokosmisk, hvad der makrokosmisk skal ske på dommedag (1. Kor 11,23-34).

Endvidere kan disse eskatologiske temaer også i vid udstrækning findes i beskrivelser af og refleksioner over dåben fra samme periode. ${ }^{34}$ Bortset fra Tertullians De Baptismo og Didake 7 kan man også nævne Justin Martyr, der tilsyneladende forbinder Åndens komme i dåben med den eskatologiske vision i Esajas 11,35 eller Hermas Hyrden 15,3-4. Hvis vi i forbindelse med Thomasakterne, der ligesom Didake 7 er behandlet ovenfor, holder os til de allerede nævnte passager (26-27 og 131-133), så kan det konstateres, at der også her alle forskelle til trods er flere eskatologiske træk. I beretningen om Gad og hans broders dåb (26) slås det fast, at dåben og den efterfølgende deltagelse i nadveren gør fuldkommen, en term der er præcedens for at forstå eskatologisk (jf. Didake 16,2). Om omtalen af lys og mørke i 27 har eskatologiske konotationer, er et åbent spørgsmål. I 131-133

30. Jf. IgnEph. 20,2. I virkeligheden kan denne passage måske illustrere den anden og mere positive side af 1 . Kor 11,23-34, hvor Paulus synes at hævde, at eukaristien foregriber dommen ved Gudsrigets komme, idet de, der spiser Herrens brød og drikker hans bæger uværdigt, allerede nu straffes med sygdom og død.

31. Jf. A. Gelston, The Eucharistic Prayer of Addai and Mari, (Oxford: Clarendon Press 1992), f.eks. 55 (H 56-59).

32. 1. Klemensbrev, Polykarps Martyrium 14,2 etc.

33. Luk 22,14-18. Ganske vist siger Jesus ikke eksplicit, at han vil faste, men alene, at han hverken skal spise det (påskemåltidet?) eller drikke af vintræets frugt, før Gudsriget er kommet. Dette er her tolket som en intention om at faste indtil Gudsrigets komme.

34. Jf. f.eks. Tertullian De Baptismo XIII 4.3.1, eller Didake 7. Dog kan Didake 7 rimeligvis kun læses eskatologisk, hvis det på en eller anden måde relateres til de foregånde seks kapitler.

35. Jf. E.C Ratcliff, “Justin Martyr and Confirmation”, Theology 51 (1948), 133139. 
omtales dåben dels som det, der føder mennesket på ny og dels det, som gør mennesket i stand til at deltage i nadveren, der her omtales som "livets brød", og muligvis skal forstås på samme måde som f.eks. Ignatius' omtale af nadverbrødet som "udødelighedens medicin" (IgnEph. 20,2). Der synes altså at være tale om, at der også i forbindelse med dåben er klare eskatologiske elementer på spil på dette tidspunkt.

Ikke alene er kilderne til dåb og eukaristi i det 2. årh. sparsomme, dette gælder dobbelt, når man ønsker at gøre brug af kilder, der nævner dåb og nadver i fællesskab. I de få tilfælde, hvor dette er tilfældet (Didake 7-11, Thomasakterne 131-133), synes der at være en tendens i kilderne til at hævde, at mens dåben bringer de troende ind $\mathrm{i}$ det fællesskab med den opstandne Herre Jesus Kristus, hvor de er i stand til at fejre eukaristien, er eukaristien det sted, hvor de er i stand til at prefigurere det kommende eskatologiske måltid.

Selvom jeg ikke vil gå i detaljer, bør det dog nævnes, at offerbegreber ofte blandes med eukaristi- og dåbstekster, ${ }^{36}$ og eukaristien bliver ofte fremstillet som det åndelige offer, som Mal. 11 profeterede om. Dette er i sig selv ikke bemærkelsesværdigt, eftersom offeret eller i det mindste en klar forestilling om offeret som åndelig størrelse var en uundværlig del af enhver religion i det 2. årh., som ønskede at blive taget alvorligt, men når det kombineres med de ovenfor nævnte emner, åbner der sig en mulighed.

Jeg vil hævde, at det er muligt at fortolke kildernes udsagn som følger: Den tynde røde tråd, der holder de forskellige eukaristi og dåbsriter i det 2. årh. sammen, er en fælles overbevisning blandt de tidlige kristne, der kommer til udtryk gennem deres riter og reflektioner over samme: Dåb og eukaristi er henholdsvis porten til og prefigurationen af det eskatologiske glædesmåltid, som Gudsfolket, dvs. den kristne menighed, der udgør et folk af præster, allerede nu fejrer.

\section{Konklusion}

Selvom denne hypotese må efterprøves gennem stadig diskussion, så kan den dog foreløbig etableres som et holdbart alternativ til hypoteser, der opererer med en minimalistisk terminologi.

36. Jf. f.eks. Didake 14 og IgnRom 14,2 eller PolMar 14-15, hvor Polykarps martyrdød både antager karakter af en eukaristi og af et offer. 